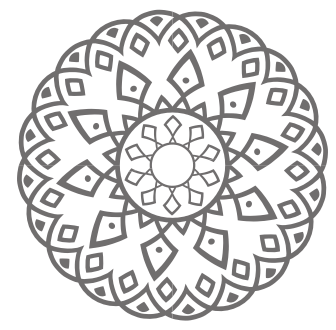

\title{
Strategies for Combating Sexual Harassment in Islamic Higher Education
}

\author{
Istiadah, Aprilia Mega Rosdiana, Laily Fitriani, Sulalah
}

\begin{abstract}
Abstrak: Serangkaian pelecehan seksual yang dipublikasikan secara luas di Universitas Islam Negeri (UIN) Maulana Malik Ibrahim Malang baru-baru ini menimbulkan pertanyaan tentang bagaimana kampus Islam ini menangani situasi dan mendorong perubahan kelembagaan. Penelitian ini mengkaji pelecehan seksual dan cara UIN menanganinya. Penelitian ini menggunakan penelitian aksi partisipatif agar peneliti dan pemangku kepentingan dapat bekerja sama untuk mengetahui strategi pencegahan pelecehan seksual. Penelitian ini memperoleh tiga strategi untuk mencegah dan memberantas pelecehan seksual antara lain strategi perencanaan yang komprehensif, pembangunan infrastruktur, dan membangun kemitraan kunci. Kemitraan tersebut mencakup revitalisasi fungsi konselor akademik, kampanye anti pelecehan seksual, pembuatan situs web yang berisi konten positif, pemaduan pendidikan seksual dengan kurikulum pembelajaran, dan menjaga hubungan dengan camat di sekitarnya untuk dikontrol siswa. Penelitian lebih lanjut diharapkan untuk memeriksa dan merefleksikan hasil dari tindakan yang dihormati untuk menemukan protokol pencegahan, intervensi, dan kebijakan yang paling sesuai untuk perguruan tinggi Islam.
\end{abstract}

Kata kunci: Kampus Islam; Pelecehan Seksual; Pencegahan; Strategi; Kebijakan 
Abstract: Recent series of widely-published sexual harassment at Maulana Malik Ibrahim State Islamic University (UIN) Malang arise a question on how this Islamic campus handles the situation and promotes institutional change. This research examines sexual harassment and the way the UIN deals with it. It employs participatory action research to make it possible for researchers and stakeholders to work together to find out the strategies to prevent sexual harassment. This research obtains three strategies to prevent and combat sexual harassment including comprehensive planning strategies, infrastructure development, and building key partnerships. These partnerships include revitalizing the functions of the academic counselor, conducting campaigns against sexual harassment, building a positive-content website, integrating sexual education with the learning curriculum, and keeping relationships with the surrounding sub-district heads for the students' control. Further research is supposed to examine and reflect on the result of the respected actions to find out the most suitable prevention, intervention, and policy protocols for Islamic higher education.

Keywords: Islamic Campus; Sexual Harassment; Prevention; Strategies, Policy 


\section{Introduction}

The increasing number of sexual violence in the public domain recorded by the National Commission on Violence Against Women is in line with the increasing coverage of violence and sexual harassment in the scope of higher education in 2019. One of the examples is the case of Agni (not real name), a female student of Gajah Mada University (UGM) who experienced sexual harassment while undergoing a community service in June 2017. After a long process in February 2019, the UGM rectorate met Agni and the alleged HS actors to sign a settlement agreement through a non-litigation channel. Agni felt that UGM campus was not firm in stating that the case she experienced was a case of sexual violence (Ulya, 2019). The next case is sexual harassment experienced by Flora (not her real name), a student of the University of North Sumatra (USU), in February 2018. The harassment was committed a lecturer majoring in Sociology. Flora experienced the harassment on her way to campus, when the street was quiet. A year passed, the lecturer only received a warning letter from the department without letterhead, and an official university stamp and the lecturer was still teaching at USU's Faculty of Social Sciences (Andriansyah, 2019).

Islamic higher education institutions, on the other hand, do not mean less prevalence compared to other non-religious institutions. The online newspaper Tribun Lampung reported that an individual lecturer from the State Islamic University (UIN) Raden Intan underwent a hearing at the Tanjungkarang District Court on Tuesday, July 23, 2019, on suspicion of obscene acts to a student with the initial EP. She met the perpetrator in front of the lecturer room to collect her assignment. The perpetrator entered the lecturer room, followed by the victim and sexually abused her in that room (Mustafa, 2019). Another viral case is sexual harassment by the lecturer of the Bandung UIN against some of his students. The campus has formed a special team to examine the case, but the campus commitment to take action on the case is doubted by a number of parties. Some victims did not want their cases to be revealed because they were afraid of the disruption in their education process (Wijaya, 2019). The Malang UIN was shocked by the news that was spread online. An online newspaper, Tirto.id, reported three victims of sexual harassment by the same perpetrator. 
One of the victims was Ratih (not her real name). She was afraid of the possible campus intimidation and the harmful effects that may occurred when recounting the bad experience (Ulfa, 2019).

Scholars have noted how universities respond to sexual harassment in various campuses around the world (Schmiede and Yousaf, 2016). Klein (2019) has studied extensive literature published since 2000 on sexual harassment among college or university students. Likewise, DeMatteo et al (2015) studied sexual violence on campuses by analyzing fifty laws on sexual crimes and their relevance to sexual violence happened on campuses. Reena and Saheab (2014) studied how campus stakeholders respond to sexual harassment. Cantalupo and Kidder (2018) found that students were dissatisfied with legal policies governing sexual violence on campus, and most universities kept the incidents to themselves. This research found that the majority of sexual harassment cases on campus were related to physical contacts such as groping, sexual violence, and other physical violence, and the perpetrators were suspected lecturers. Phipps (2018), through his twelve-year ethnographic research, stated that there is no serious institutional action addressing the problem of sexual harassment and violence. The issue of sexual violence is influenced by the gender context and power relationship between perpetrators and victims. Many factors underlie this sexual harassment. Fuadi (2011) maintained that among the factors that support sexual harassment are negligence of parents who ignore the growth and development of their children; the low mentality of the offender; and economic factors. The latest is used by offenders to lure the victim

Many studies have shown that sexual harassment cases have developed rapidly, including sexual harassment in the context of education. However, studies on Islamic tertiary education are still very limited despite the increasing trends. This study departs from two questions: 1) How is the situation at the Malang UIN related to the sexual harassment cases? 2) How has the Malang UIN responded to the problem? This study explores how the Malang UIN promotes institutional changes to prevent sexual harassment and to overcome existing conditions. This study will also explore specific cultural contexts that have an impact on the idea of sexual harassment, which in this case is related to Islamic teachings. It is expected that this study 
find a model of of sexual harassment prevention and intervention for Islamic higher education.

\section{Forms of Sexual Harassment}

Boateng at al. (2015) reveals that the concept of sexual harassment is not well understood in the international and national arenas. Previous research has revealed that it is difficult for them to impose limits on the definition of sexual harassment for various reasons. Pralhadrao (2014) states that sexual harassment is one of the most violating forms of violence. Bowling and Beehr (2006) found that the forms of sexual harassment can be minor such as obscene gestures, dirty looks, threats, shouting, whistling, giving the silent treatment, disparaging, etc. May include murder and physical assault. Aditi et al. (2016), who studied 408 undergraduate students from selected professional colleges, found that scholars' perceptions about sexual harassment differed from others in relation to their age, gender, and study program. Apaak and Sarpong (2015), who studied in Ghana, stated that most women did not understand what sexual harassment meant because the definition was a bit confusing with the definition of rape. Hlavka, Heather R (2014) found that the people they studied did not question actions that, according to researchers and educators, were considered sexual harassment or merely harassment because such actions were considered normal. Another reason for the difficulty in defining sexual harassment is that people find it difficult to draw a line between flirting, playing games and sexual harassment

Meyer (1987) states there are two important aspects of sexual harassment, behavioral aspects and situational aspects. The Behavioral Aspect is an unwanted sexual seduction from the recipient, in which seduction appears in various forms: smooth, rough, open, physical and verbal seduction. In general, a form of sexual harassment can be verbal and physical temptation, while verbal abuse is more than physical one. Experts cite verbal abuse as unexpected sexual persuasion, jokes or persistent sexual messages; asking to meet continuously even if the request is rejected; derogatory or degrading messages; suggestive or obscene comments; sexist expressions about clothing, body, women's clothing or sexual activity; requests for sexual services stated as indirect or open threats. The second aspect is the situational aspect. Sexual 
harassment can be done anywhere and with certain conditions. Victims of sexual harassment can come from various races, ages, individual characteristics, marital status, social class, education, occupations, workplace, and level of income. Pavithra and Relton (2015) found various forms of sexual harassment ranging from exposure to strong genitals to physical touch in public places.

In Indonesia, some researchers define sexual harassment as follows. Wirasunu (in Nurdiana, 2019) defines sexual harassment as sexual behavior against the will of the victim, which results in feelings of abuse. Some acts of harassment that refer to sexual harassment are forced sexual activity, derogatory statements or sexually-oriented jokes, requests for sexual acts, and sexual sayings or connotations. These actions are rude, either directly or indirectly delivered to the victim (Triwijati, 2007). Sexual harassment can also be interpreted as a sexual connotation that is said unilaterally without the victim's willingness. This can be in the form of speeches, writings, symbols, gestures and sexual overtones. According to Wirasunu, sexual connotation activities can be considered sexual harassment if they contain the following elements: unilateral coercion from the perpetrator without victims' approvals, and that causes the victims to suffer (in Nurdiana, 2019). Wahid and Irfan (2001) state that sexual harassment refers to behaviors that lead to a sexual activity carried out in unexpected ways, which can cause adverse reactions, such as shame, anger, hatred, and violation. These include cheeky whistling, teasing, sexual connotation comments, porn humor, poking, pinching, patting or touching certain body parts. These cues constitute a sexual solicitation, solicitation of dating, solicitation for sex, and rape. Fitzgerald and Ormerod (1991) identified five forms of sexual harassment in the university environment, namely gender harassment, seductive behavior, sexual bribery, sexual coercion and coercion or sexual assault.

This study uses 15 types of sexual violence found by the National Commission on Violence Against Women (Komnas Perempuan) as a result of its monitoring for fifteen years (1998-2013). These include: 1) rape; 2) sexual intimidation, including threats or attempted rape; 3) sexual harassment; 4) sexual exploitation; 5) trafficking of women for sexual purposes; 6) forced prostitution; 7) sexual slavery; 8) forced marriage, including hanging divorce; 9) forced pregnancy; 10) forced 
abortion; 11) Forced use of contraception and sterilization; 12) sexual torture; 13) inhuman and sexual-nuanced punishment; 14) traditional sexual practices that endanger or discriminate against women; 15) sexual control, including through discriminatory rules based on morality and religion.

\section{Campus Responds to Sexual Harassment}

Amar, AF et al. (2014) observed three areas of campus response to sexual harassment, namely campus protocols and responses to attacks; adjudication of campus attacks; and provision of education prevention of students about sexual violence. They suggested that campuses need to increase their role in dealing with sexual harassment.

\section{Implications for Improving Campus' Response and Further Research on this Matter}

Aina \& Kul (2018) show the importance of universities in making policies in responding to sexual harassment. They said that the Indian Government formulated a circular for central government employees on February 13, 1998. On September 3, 2012, Sexual Harassment of Women at Work, Prevention, Prohibition and Compensation was approved by the Lower House of Parliament. Then it was confirmed by the Parliament on February 26, 2013; and received the approval of the President on April 22, 2013. However, the policy began to be effective from December 9, 2013. In May 2016, the University Grants Commission only realized the 'Law' to protect working women, so the Commission also amended the rules and regulations to be gender neutral to protect educational institutions in general. They said that the existence of a sexual harassment policy alone is not enough to stop sexual harassment. If there is no awareness and ongoing training, the struggle to eradicate sexual harassment will be entirely in vain.

Dills J et al. (2016) offer a comprehensive approach to preventing sexual violence on campus. There are five components to efforts to prevent sexual violence on campus. The integration of the five components is believed to have a more significant impact on the reduction and prevention of sexual violence on campus. The five components are comprehensive prevention, infrastructure, hearings, 
partnerships and evaluation. Comprehensive prevention means strategies and approaches that support each other from the individual level to the community across social ecological models. The approach uses a four-level social ecological model to promote a proper understanding of sexual harassment. The four levels are individuals, relationships, community and society. To have a comprehensive strategy and approach, the prevention and treatment of sexual harassment must be multi-layered from events after sexual violence to further services that address follow-up and long-term support. This comprehensive program also mandates that students who have just entered university, new students, be given training on sexual violence. The target is not only to receive one-time training, but the right formula must be determined and sufficiently facilitated by trained facilitators using methods that are varied and in accordance with the cultural and ideological background of the audience. An evaluation must also accompany the training

\section{Victims' Responses to Sexual Abuse}

Sexual harassment experienced by victims results in a very detrimental impact, in terms of psychological, sociological and biological aspect of the victims.

The psychological effects that will occur on victims of sexual harassment are as follows:

1. Behavioral disorders which are characterized by laziness to do daily activities;

2. Cognitive disorders, characterized by difficulty of concentrating, unable to focus on learning, often daydreaming and pensive;

3. Emotional disorders, characterized by mood disorders and selfblaming.

Furthermore, Kendall-Tackett et al., in Sakalasastra and Herdiana (2012) and (Fuadi, 2011), explained that victims who experience sexual abuse tend to have problems with anxiety, such as depression, vengeance, guilty feelings, prolonged sadness and will likely to experience PTSD (Post Traumatic Stress Disorder) that occurs due to traumatic experiences and depression that threaten the life of the victims. So it can be explained that victims who have experienced sexual harassment will feel a disturbance in their lives, and it takes 
a long time to get back up because the majority of victims do not want others to know what has happened to their lives. Therefore, it is necessary to take serious care of the victim without cornering the victim's existence.

\section{Method}

This study examines strategies maintained by the Malang UIN in combatting sexual harassment using the Participatory Action Research (PAR) method. Lewin (1990) suggests that action research is a process that includes: planning of actions that involve careful and thorough investigation, implementation of actions in activities, the discovery of facts and phenomena about the results of actions, and discovery of new meanings from social experience. PAR encourages researchers and people who benefit from research to work together fully in all stages of research. All relevant parties (stakeholders) are actively involved in assessing phenomena to make changes and improvements. Therefore, the main reason underlying the use of the PAR method is the need to take collective action to achieve the desired change (Afandi et al., 2013).

The above definition concludes that PAR requires certain community experiences and their participation in data collection and analysis.

This refers to the theory of O'Brien (2001) as follows:

Figure 1. Participatory Action Research Model (PAR)

(adapted from MacIsaac, 1995)

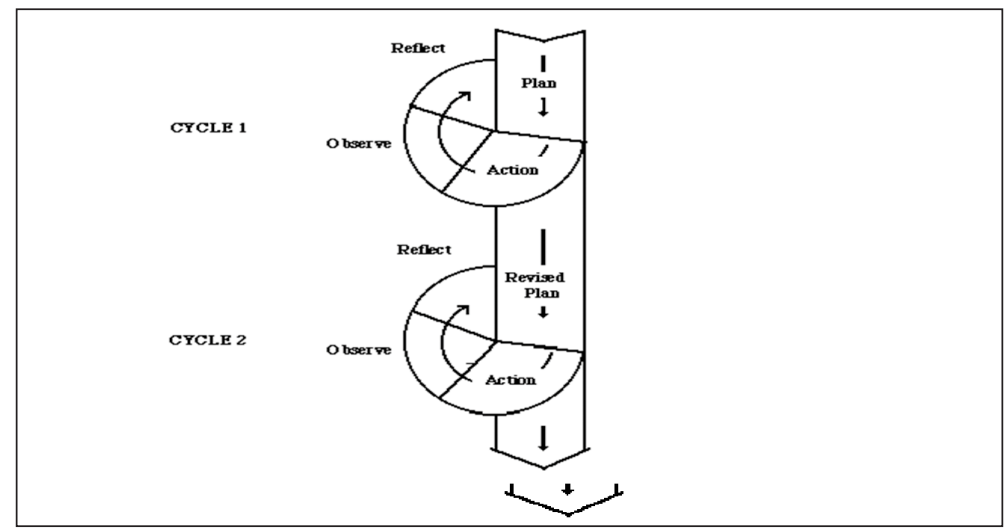


The above scheme shows that the Participatory Action Research process involves the following five main stages: first, problem identification. As the first purpose of this research is to find out the conditions in the Malang UIN, this research requires a large number of participants. The survey design was used because of its suitability for research with relatively large samples. The researchers initially conducted a survey to map sexual harassment and violence in the Malang UIN. This research uses descriptive research type survey design. The population consisted of 237 respondents, both men and women, who participated by filling out questionnaires that were distributed via Google forms. The questioners used are the forms of sexual harassment established by the National Commission on Violence Against Women.

The second step is Planning. The team of researchers and the UIN stakeholders plan and determine the steps to find a solution. In this process, stakeholders are involved in identifying the causes of sexual harassment and violence to plan alternative solutions and to prevent sexual harassment. Stakeholders involved are: internal campus unit, those are Center for Gender and Child Studies (PSGA); Psychological service institutions in the Faculty of Psychology; and legal service institutions in the Sharia Faculty.

The third step is Action. At this stage, two activities are done. The first activity is FGD (focused group discussion) with related parties to find a mechanism for handling victims and perpetrators of sexual harassment; and protection and consultation of victims with UIN Malang services in the Faculty of Psychology and the Faculty of Sharia. The second activity is training. This is training is intended for service providers, especially complaint centers at the PSGA and peer counselor. The fourth and fifth steps are evaluation and reflection. The evaluation was conducted jointly by the research team and related parties. This is to measure the progress that has been made through the instrument and FGD. Reflection is carried out to measure success and revise actions. This action is carried out as a platform to take further action through the next cycle. 


\section{Research Result}

\section{Sexual Harassment at the Malang UIN}

Based on a questionnaire distributed to students using the Google Drive page, 237 respondents answered. In the questionnaire, there are 22 questions. The following are the respondents' answers:

Graph 1. Distribution of the Number and Forms of Sexual Harassment

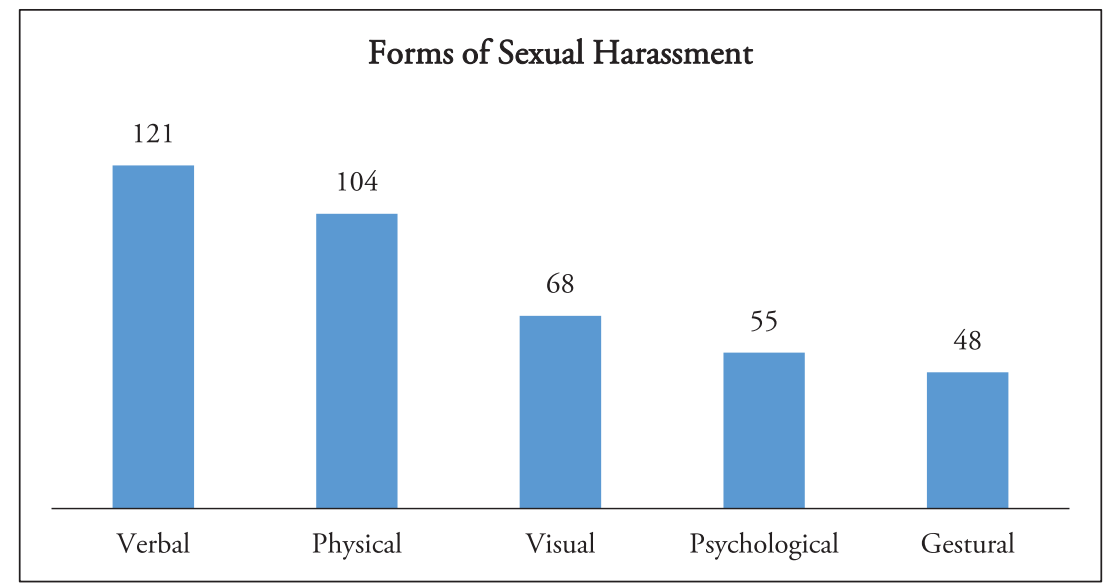

Graph 1 shows the form of sexual harassment experienced by the respondents and the number of victims at the Malang UIN. The data shows that 121 of $237(51 \%)$ of the total respondents experienced sexual harassment in the form of verbal abuse such as unwanted comments about personal and sexual life or body parts or appearance; sexual jokes; sexual commentary; and sexually-oriented whistling. A total of 104 students (44\%) were victims of physical, sexual harassment. Physical abuses are in the form of unwanted touches that lead to sexual acts such as holding, patting, kissing, pinching, hugging, stroking, glueing bodies or other physical touches unwanted by the victim. While students who have experienced sexual harassment visually, such as displaying pornographic material, screensavers or posters of a sexual nature, or harassment via e-mail and other electronic communication modes, amounted to 68 (29\%). The graph also shows that 55 (23\%) of students experienced psychological, sexual harassment such as unwanted requests and repeated invitations to engage in sexual activities, unwanted dating 
invitations, and sexual insults. Then, as many as 48 (20\%) of students experienced sexual harassment through cues such as body movements, eye twitching, repeated glances, movements with fingers, and licking of the lips.

Table 1. Distribution of Sexual Harassment Perpetrators

\begin{tabular}{|lc|}
\hline Sexual Harassment Perpetrators & Jumlah \\
\hline People they do not know & 54 \\
Students & 34 \\
Friends & 25 \\
Relatives & 4 \\
Lecturers & 3 \\
Security (Satpam) & 2 \\
Educational staff & 2 \\
The neighbor & 2 \\
Seniors (kakak kelas) & 1 \\
Private tutor & 1 \\
Employer & 1 \\
Total & 129 \\
\hline
\end{tabular}

The table above shows that perpetrators who sexually abused the Malang UIN students were people they don't know (54), students (34), friends (25), siblings (4), lecturers (3), security guards (2), education staff (2), neighbors (2), private tutors (1), seniors (1), and the employer (1). The data shows that the parties who committed the most sexual harassment were people unknown to the victims (41\%). In the second place, most perpetrators of sexual harassment are students (26\%) and friends (19\%). 
Graph 2. Distribution of Responses of Victims of Sexual Harassment

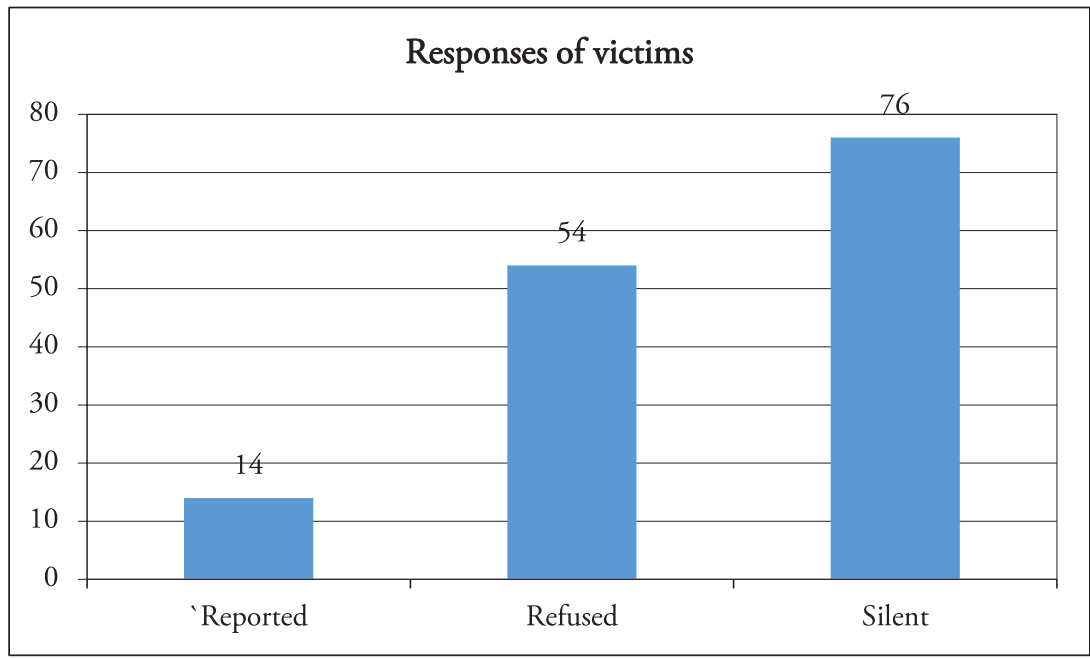

Based on data from students who have been sexually abused, $76(32.02 \%)$ of them chose to remain silent, $54(22.28 \%)$ of them refused to talk about the harassment, and only 14 (17.79\%) of them reported the incidents.

\section{Sexual Violence at the Malang UIN}

In addition to sexual harassment, this research also collected information about sexual violence experienced by students on campus. The types of sexual violence being explored are rape, sexual intimidation, sexual exploitation, forced prostitution, forced marriage, forced pregnancy, forced abortion, forced coercion and sexual torture.

The graph shows the number of students who experienced sexual violence at the Malang UIN. There were 4 students out of 237 students who filled out the questionnaire became rape victims. The data also shows that 13 students have experienced sexual intimidation, which is an act that attacks sexuality to cause fear or psychological suffering to women victims. Sexual intimidation can be conveyed directly or indirectly through letters, SMS, e-mail, and others. Threats and attempted rape are also part of sexual intimidation. The number of students who have experienced sexual exploitation is 11 students. 
Sexual exploitation is an act of abuse based on unequal power, or abuse of trust for sexual satisfaction, as well as to obtain benefits in the form of money, social or political benefits, and others. The form of sexual violence in the form of forced prostitution was also experienced by two students, namely a situation where a person experienced deception, threats and violence to become sex workers. Sexual violence in the form of sexual slavery was also experienced by two students. That is a situation where the perpetrator feels that he is the owner of the victim's body and he has the right to do anything, including obtaining sexual satisfaction through rape or other forms of sexual violence. Four students experienced sexual torture, sexual torture is a particular act of attacking an organ and a person's sexuality, which is done intentionally, causing great pain or physical, spiritual and social sufferings.

Graph. 3. Prevalence of Sexual Violence

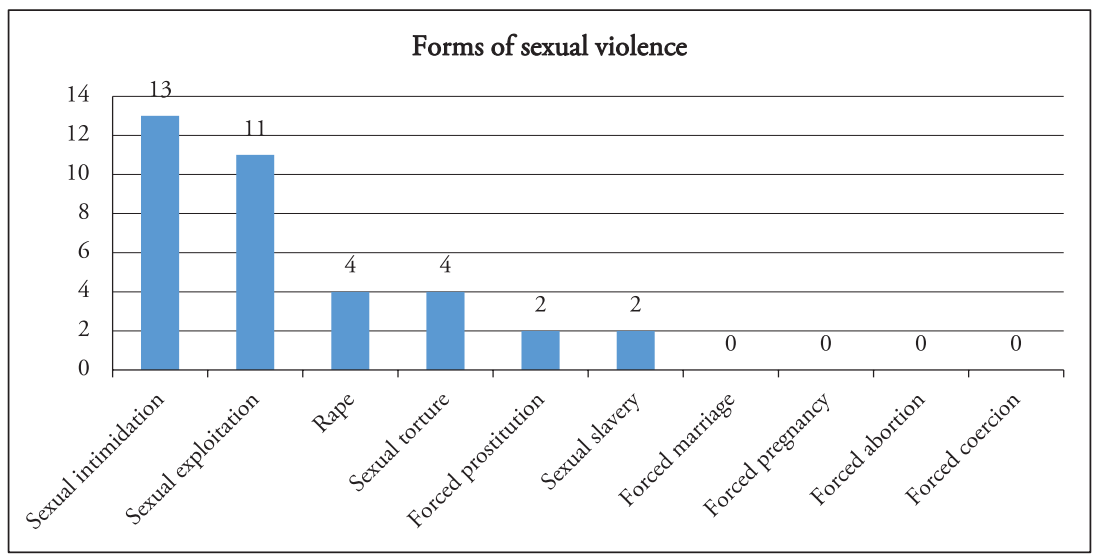

The table above shows that the perpetrators of sexual violence varied. The highest number of perpetrators of sexual violence were unknown to the victims, 17 people (47\%). The data also shows that in the second place, the perpetrators of sexual violence are students $(25 \%)$. The diagram above also shows that families are also perpetrators of sexual violence so that victims experience sexual violence as well as those closest to their environment (11\%). Perpetrators of sexual violence may come from an educational environment, and they are respected people, as shown by the diagram above that lecturers, 
education staff, seniors, opponents and alumni become perpetrators of sexual violence.

Table 2. Distribution of Sexual Violence Perpetrators

\begin{tabular}{lc}
\hline Perpetrators & Numbers \\
\hline Strangers & 17 \\
College male students & 9 \\
Relatives & 4 \\
Faculty staff & 2 \\
Lecturer & 1 \\
Senior & 1 \\
Alumni & 1 \\
Opponent & 1 \\
Total & 36 \\
\hline
\end{tabular}

\section{Strategies to Combat Sexual Harassment}

Three strategies embody the main message agreed upon in Focused Group Discussions conducted with the Malang UIN stakeholders. These strategies represent the framework of efforts to prevent sexual violence on campus. The integration of all components offers the opportunity to implement prevention efforts to have a more significant impact on preventions and interventions to combat sexual harassment at the Malang UIN. These strategies include: planning a comprehensive approach; infrastructure development; and key partnerships. The planning of comprehensive approach to prevention in the first strategy refers to strategies and approaches that complement and strengthen each other. Activities and strategies must be carried out at the individual level, relationship level, and the community level. Cross social-ecological activities can complement and strengthen each other. Starting from the first-day students enter campus life to their last day at the campus. The Malang UIN policyholders agree to maintain several strategies:

The first strategy is to provide services for new students to help them adapt with the campus environment, especially students who 
graduate from Islamic boarding schools who are not accustomed with socializing with the opposite sex. These services include:

a. Providing information for new students about sexual violence and strict sanctions against perpetrators during Campus Orientation Program (PBAK);

b. Providing information for new students about the effects of sexual behavior from psychological, physical aspects and their impact on academic achievement during Campus Orientation Program (PBAK);

c. Providing services, such as psychological, reproductive, gender and legal consultations that can be accessed by all people at Maulana Malik Ibrahim Malang UIN.

d. Training students to protect themselves from invitations to sexual violence behavior through sex education for students and knowledge about sexually transmitted diseases.

e. Upholding engaging student activities to channel youth energy as an educational and creative experience for students,

f. Promoting sexual education in the curriculum.

The second strategy is building a preventive infrastructure. Infrastructure refers to the basic system and organizational structure needed to implement sexual harassment prevention strategies on university campuses effectively. To prevent sexual harassment, The Malang UIN formed "Duta Sahabat Curhat" (peer consultant) who can mediate the victims (students) and campus staff. To improve their skills and knowledge to deal with sexual harassment, 20 "Duta Sahabat" students are trained. The training is conducted to strengthen knowledge and practice in counseling, communication, teamwork and spiritualism. Training materials include understanding the unequal gender relations between men and women and reproductive health rights. The latter includes how to respect client choices, client rights and client learning methods. Finally, the basic counseling and peer counseling material are related to how students know the attitudes in and basics of counseling, and how students can become counselors for those with the same age by considering the perspective of the victims. The results of the training will be able to improve participants' knowledge and skills in helping other students who are in trouble. Also, one important infrastructure 
to deal with and prevent sexual harassment is policies on campus that allow and enhance the prevention efforts. The agreed policy during the FGD is the need for campus regulations that have a gender perspective and anti-sexual violence. This includes campus policies to filter and strict the access to pornographic sites.

The third strategy is building key partnerships to maintain prevention. The Malang UIN needs to collaborate with the nearest Islamic boarding schools to provide alternative housing options for post-makhad (Islamic boarding school) students. The UIN will also cooperate with RT / RW (Neighborhood Unit/ Community Unit) in protecting the Malang UIN students around boarding houses or rented houses from violations. Last but not least, UIN needs to work together with community organizations and the Woman Crisis Center (WCC). Working closely with community-based crisis centers can ensure the coordination of strategies to prevent sexual violence in the community and on campus.

\section{Discussion}

This research revealed that there were various types of sexual violence in the campus environment. This is in line with previous research (Rinehart, 2016; Schmiede \& Yousaf, 2016; Klein et al, 2019; DeMatteo, 2015; Reena \& Saheab, 2014; Contalupo \& Kidder, 2018; Phipps, 2018). This study finds that respondents experienced more sexual abuse, compared to sexual violence. This finding is supported by Klein's research (2019) that sexual and gender abuse is more often experienced than sexual violence. Sexual harassment has various forms including, verbal sexual harassment, physical sexual harassment, sexual harassment through images, sexual harassment in the form of gestures and sexual harassment through image cues.

This research shows that $36 \%$ of sexual violence cases experienced by students are sexual intimidation. Sexual intimidation is an act that attacks sexuality to cause fear and psychological suffering to victims, directly and indirectly, such as attempted rape and threats through letters, messages on social media, e-mail, and others. This study is in line with Beedy's study (2018) that 50\% of respondents have been sexually intimidated, one-fifth reported that the perpetrators are people who use their authority. 
Furthermore, this research reveals that victims of sexual harassment prefer silence over fighting the case or reporting the incidents. This is in line with Bates's research (2017) which states that most victims of harassment are haunted by fear if they report abuse, this includes victims experiencing fear of reprisal from perpetrators. In addition, the victims' perception and knowledge of sexual harassment that they experienced is often understood as an individual and environmental responsibility. This is because of consideration that some sexual harassment acts are normal. This makes the victims feel reluctant to report to the university (Guschke, 2019). Only a few victims dared to report. Pinchevsky (2019) mentioned that when victims dare to report, they will feel intimidated and uncomfortable. This, in turn, can bring various negative impacts on victims. Klein's research (2019) revealed that victims experienced various mental health problems and the physical consequences due to sexual violence experienced. In addition, sexual violence hampers victims' life achievements (Yusaf, 2016). Adolescent girls who experience violence or sexual harassment are more likely to engage in risky sexual behavior later in life (Seth, 2010).

In this study, the perpetrators of sexual harassment (42\%) and the perpetrators of sexual violence $(47 \%)$ are unknown people or other people who do not have a relationship with the victims. This finding corroborates the Komnas Perempuan Annual Record data (2019), stating that perpetrators of sexual violence in the realm of the community are unknown people and others (36\%). This research shows that in the second place, the perpetrators of harassment and violence are fellow students or friends. This means that students need to be aware of sexual harassment and violence. Actors who are staff and lecturers in this study are relatively small compared to the findings of Beedy (2018).

Several parties have carried out efforts to prevent and overcome sexual harassment and violence on campus. Through a series of activities, this research obtained three strategies to prevent and combat sexual harassment on campus, including comprehensive planning strategies, infrastructure development, and building key partnerships. This strategy is in line with the five strategies offered by Dills (2016), namely comprehensive prevention, infrastructure, audience, partnerships and evaluation. 
The first strategy found in this research is comprehensive planning. This include the campus' collaboration with various parties in realizing sexual violence prevention activities such as providing services that help new students to socialize and consult about the adaptation with the campus environment; providing information about reproductive health, impacts and sanctions related to violence cases sexual during the student orientation program. Moreover, providing information to students about the forms and locations prone to sexual violence is also very important so that the students are able to recognize and understand howto prevent sexual violence (Espelage, 2016). Gender and sexual education must also be included in the curriculum, in order to promote and shape students' understanding of gender roles and the prevention of sexual violence.

The campaign against sexual violence is not enough to be done once or twice. Still, it must be carried out many times through activities that are interesting for students and university residents. The existence of facilitators who have been trained by the university spearheading to disseminate important information about behavior that can prevent sexual violence on campus. Social campaigns related to common and ongoing sexual violence are also crucial. Such social campaigns become the vanguard to invite all university residents to help prevent and minimize sexual violence on campus. Gender-responsive policies from campus stakeholders are also essential in supporting the prevention of sexual violence on campus.

Willness (2007) states that one of the predictors of sexual violence in an institution is the climate of the organization. It is necessary to grow an organizational climate that creates a healthy and safe climate from sexual violence. In line with Bates's (2017) research, the campus can strive to create a safe environment by removing negative stigma for victims; willing to provide training for victims; and be able to bring the issue of sexual violence to be discussed at scientific meetings. This comprehensive planning explains that the prevention is not only carried out to individuals but also to broader levels of social scopes, such as student dormitories, families, departments, faculties, universities and the community. In the context of the level in social ecology theory, the levels are complementary and mutually reinforcing. 
The second strategy is the development of infrastructure in the form of systems and organizational structures needed to prevent sexual violence on campus, such as the services of "Sahabat Curhat". It is a service from students for students in the form of peer counseling, discussion and the promotion of sexual violence prevention services. Sahabat Curhat is an institution for preventing sexual violence where the members of the confide are lecturers, and students who have been trained in knowledge and skills to provide services and activities to prevent sexual violence. Sahabat Curhat will be taught about the administration of reporting sexual violence incidents on campus so that the data obtained can be used as a reference for further prevention programs. This is also to strengthen the efforts of preventing sexual violence from time to time. In addition, the campus has a commitment to make campus policies that have gender and anti-sexual violence perspectives, such as promoting sexual violence prevention posters on the academic online system and facilitating access to reporting procedures for sexual violence on the university web. The campus leadership's policy is to filter the web so that university residents cannot access pornographic sites easily. This second strategy is in line with the study of Dills (2016), finding that optimizing sexual violence prevention strategies involves three things: employment, office space, and the presence of policies on college campuses.

The third strategy in the Malang UIN is to build key partnerships to strengthen prevention efforts through building good relations with various stakeholders and communities. Among these communities are Islamic boarding schools around the UIN; RT / RW (Neigborhood Unit/ Community Unit); and other organizations. This key partnership is in the form of a working group or team that collaborates across institutions, such as campuses, government agencies, health centers and community organizations. The community organizations are woman crisis centers, advocacy agencies, cultural centers, and other organizations related to the prevention and treatment of sexual violence. This key partnership needs to be maintained because besides prevention in handling cases, support and treatment from various institutions, such as counselors, psychologists and advocates, are needed. Dills (2016) mentions that developing good relations with 
stakeholders and community partners can strengthen prevention efforts and sustainable interventions.

The practical implications of the findings of this study help agencies, especially Islamic university agencies, to be more concerned about sexual violence cases, especially sexual harassment and sexual intimidation. Sexual violence cases can occur in various forms, such as sexual comments, physical, gestures, images, and others. The findings of this study can provide solutions by proposing various efforts that can be made by agencies in preventing sexual violence. Policymakers can make policies that can be enforced consistently through clear definitions of sexual violence and strict regulations to prevent sexual violence. Furthermore, there is a need for guidelines in the form of standard operating procedures in dealing with cases of sexual violence.

\section{Conclusion}

This study concludes that sexual harassment and violence occurred on-campus residents. The survey reveals that many students of UIN Malang became victims of abuse from strangers, friends and fellow students. There are also staff and lecturers, although their percentage is small. Various handling strategies have been carried out, ranging from development of policies, the establishment of various institutions, and the strengthening of infrastructure to prevent and combat sexual violence on campus. Using participation action research, this study reveals the existence of sexual violence experienced by respondents has also impacted on the formation of strategies in handling sexual violence on campus. Yet, this study still has limitations. This research only employs a quantitative method to map out sexual harassment on campus. This research did not getin-depth information about the experience of the victims. Therefore, qualitative phenomenological research is needed in the future studies so that they are able to see the phenomenon of sexual violence on campus in a more in-depth by also consider the perspective of the victims. This study shows broader implications for gender perspective research and gender-based violence issues. 


\section{References}

Aditi, G., Sangeetha, P., \& Binu, E. M. (2016). Knowledge of sexual harassment among the undergraduate students in Udupi district. Nitte University Journal of Health Science, 6(2).

Afandi, A. (2013). Modul Participatory Action Research (PAR) IAIN Sunan Ampel Surabaya Lembaga Pengabdian Masyarakat.

Amar, A. F., Strout, T. D., Simpson, S., Cardiello, M., \& Beckford, S. (2014). Administrators' Perceptions of College Campus Protocols, Response, and Student Prevention Efforts for Sexual Assault. Violence and Victims, 29(4).

Andriansyah, A. (2019). Mahasiswi Penyintas Pelecehan Seksual di USU Tuntut Keadilan. 26 Agustus 2019, from https://www.voaindonesia.com/a/ mahasiswi- penyintas-pelecehan-seksual-di-usu-tuntut-keadilan/4932166. html.

Apaak, D., \& Sarpong, E. O. (2015). Knowledge level and incidence of sexual harassment in sports: Views of Ghanaian female university athletes. Journal of Educational and Social Research, 5(3).

Bates. (2017) . It is Time for Zero Tolerance for Sexual Harassment in Academic Medicine. Journal of the Association of American Medical Colleges Uncomposed.

Boateng, P. A., Amponsah, E. B., Akaffo, V., \& Yamoah, P. (2015). Sexual harassment and human resource development. European Journal of Business and Management, 7(33).

Bowling, N. A., \& Beehr, T. A. (2015). Workplace Harassment from the Victim's Perspective: A Theoretical Model and Meta-Analysis. Journal of Applied Psychology (February). https://doi.org/10.1037/0021-9010.91.5.998.

Cantalupo, Nancy Chi dan Kidder, William C. (2018). A Systematic Look at a Serial Problem: Sexual Harassment of Students by University Faculty. Utah Law Review, Vol. 2018, No.3-4.

Collier, R. (1998). Pelecehan seksual Hubungan Dominasi Mayoritas dan Minoritas, Yogyakarta: Tiara Wacana.

DeMatteo, David, Galloway, Meghann, Arnold, Shelby, Patel, Unnati. (2015). Sexual assault on college campuses: A 50-state survey of criminal sexual assault statutes and their relevance to campus sexual assault, Public Policy, and Law, Vol 21(3).

Dills J, Fowler D, Payne G. (2016). Sexual Violence on Campus: Strategies for Prevention. Atlanta, GA: National Center for Injury Prevention and Control, Centers for Disease Control and Prevention. Division of Violence Prevention National Center for Injury Prevention and Control Centers for Disease Control and Prevention Atlanta, Georgia.

Espelage, D. L., Sung, J., Rinehart, S., \& Doshi, N. (2016). Children and Youth Services Review Understanding types, locations, \& perpetrators of peer-to-peer sexual harassment in U.S. middle schools: A focus on sex, racial, and grade differences. Children and Youth Services Review. https:// doi.org/10.1016/j.childyouth.2016.11.010 
Fitzgerald, L. F., \& Ormerod, A. J. (1991). Perceptions of sexual harassment: The influence of gender and academic context. Psychology of Women Quarterly.

Fuadi, M. Anwar. (2011). Dinamika Psikologis Kekerasan Seksual: Sebuah Studi Fenomenologi. Jurnal Psikologi Islam (JPI) Lembaga Penelitian Pengembangan Psikologi dan Keislaman (LP3K) Vol. 8 No 2, Januari 2011.

Guschke, B. L., Busse, K. A., Researcher, F. S., Khalid, F., \& Muhr, S. L. (2019). Sexual Harassment in Higher Education.

Hlavka, H. R. (2014). Normalizing Sexual Violence: Young Women Account for Harassment and Abuse. XX(X). https://doi.org/10.1177/0891243214526468

Kaufman, M. R., Tsang, S. W., Sabri, B., Budhathoki, C., \& Campbell, J. (2018). Corresponding author information: ce pt ed us cr t. Psychology \& Sexuality, O(0), https://doi.org/10.1080/19419899.2018.1552184.

Komnas Perempuan. (2019). Catatan Tahunan (CATAHU) Komisi Nasional Anti Kekerasan Terhadap Perempuan.

Lewin, K. (1990). Research and Action Minority Problems. The Action Research Reader. Geelong Victoria: Deakin University.

Martin, S. L. (2019). Sexual Harassment of College and University Students: A Systematic Review. https://doi.org/10.1177/1524838019881731.

Meyer, M.C., Berchtold, I.M., Oestrich, J., \& Collins, F. (1987). Sexual Harassment. New York: Princeton Petrocelly Book Inc

Morrison-beedy, D., \& Grove, L. (2018). Adolescent Girls 'Experiences With Sexual Pressure, Coercion, and Victimization: \# MeToo. https://doi.org/10.1111/ wvn.12293.

Murphy, D. (2016). Commercial Sexual Exploitation of Children and Youth in a. (July).

Mustafa, H. (2019). Oknum Dosen Diduga Cabuli Mahasiswinya di Lampung, Korban Terdesak hingga Pojok Ruang Dosen. Accessed on August 26, 2019 in https://lampung.tribunnews.com/2019/07/23/oknum-dosen-didugacabuli-mahasiswinya-di-lampung-korban-terdesak-hingga-pojok-ruangdosen?page $=$

Nurdiana. (2019). Tindak Pidana Pemerkosaaan: Realitas Kasus Dan Penegakkan Hukumnya di Indonesia.

Obrien, R. (2001). A Review of the Methodological Approach of Action Research. Toronto: Faculty of Information Studies.

Pavithra, D. A., \& Relton, D. A. (2015). Sexual abuse among adolescent school girls in Tirunelvelli district. IOSR Journal of Humanities and Social Science.

Phipps, A. (2018). Reckoning Up: Sexual Harassment and Violence in The Neoliberal University. Gender and Education.

Pinchevsky, G. M., Magnuson, A. B., Augustyn, M. B., \& Rennison, C. M. (2019). Sexual Victimization and Sexual Harassment among College Students: a Comparative Analysis. Journal of Family Violence. 
Pralhadrao, G. M. (2014). Sexual harassment in college campus. Review of Literatures, 2(5)

Reena \& O Saheab. (2014). Sexual harassment against women at educational institutions. International Journals of Science and Research.

Rinehart, S. J., \& Espelage, D. L. (2016). A Multilevel Analysis of School Climate, Homophobic Name-Calling, and Sexual Harassment Victimization/ Perpetration Among Middle School Youth, 6(2).

Sakalasastra, Pandu Pramudita dan Ike Herdiana. (2012). Dampak Psikososial Pada Anak Jalanan Korban Pelecehan Seksual yang Tinggal di Liponson Anak Surabaya. Jurnal Psikologi Kepribadian dan Sosial Vol. 1 No. 2, Juni 2012

Santrock, John W. (2007). Psikologi Pendidikan, Terj. Tri Wibowo B.S. Jakarta: Kencana, Ed. 2.

Seth, P. (2010). Intimate partner violence and other partner-related factors: Correlates of sexually transmissible infections and risky sexual behaviours among young adult African American women Intimate partner violence and other partner-related factors: correlates of Sexual Health $7(1)$.

Schmiede, R., \& Yousaf, R. (2016). Underrepresentation of women at academic excellence and positions of power: Role of harassment and glass ceiling. Open Journal of Social Sciences.

Triwijati. (2007). Memahami Kekerasan Dalam Rumah Tangga dan Menanggulanginya. Jakarta: Program Studi Kajian Wanita.

Tulus W. 2008. Psikologi Keselamatan Kerja, Yogyakarta: UMM Press.

Ulfa, W. 2019. Dosen Predator yang masih berkeliaran di UIN Malang. Accessed on August 26, 2019 in https:/tirto.id/dosen-predator-yang-masihberkeliaran-di-uin-malang-dK4i

Ulya, Y. 2019. Agni bicara: dugaan pelecehan seksual, UGM dan perjuangan 18 bulan mencari keadilan. Accessed in August 26, 2019 in https:/www. bbc.com/indonesia/indonesia-47140598.

Wahid, A. and Irfan, M. 2001. Perlindungan Terhadap Korban Kekerasan Seksual: Advokasi Atas Hak Asasi Perempuan, Bandung: Refika Aditama.

Willness, C. R. (2007). A Meta-analysis of the Antecedents and Consequences of Workplace Sexual Harassment.

Wijaya, C. 2019. Dugaan pelecehan seksual mahasiswi UIN SGD Bandung: Mengapa 'tidak pernah terungkap'? Accessed on August 26, 2019 in https:// www.bbc.com/indonesia/indonesia-47302727

Istiadah $^{1}$, Aprilia Mega Rosdiana ${ }^{2}$, Laily Firiani ${ }^{3}$, Sulalah $^{4}$

1, 2, 3, ${ }^{4}$ Universitas Islam Negeri Maulana Malik Ibrahim Malang, Indonesia

Email: ${ }^{1}$ istiadah123@gmail.com, ${ }^{2}$ apriliamegarosdiana@gmail.com, ${ }^{3}$ laily@bsa.uin-malang.ac.id,

${ }^{4}$ sulalahuin@gmail.com 